\title{
HAK GUGAT PEMERINTAH KOTA LANGSA : UPAYA PERLINDUNGAN HUTAN MANGROVE DALAM RANGKA MENEGAKKAN PRINSIP KEADILAN INTRA DAN ANTAR GENERASI
}

\author{
Nurnaningsih Amriani \\ Hakim Pengadilan Negeri Simalungun \\ Jl. Asahan KM. 4, Kelurahan Dolok Marlawan, Kecamatan Siantar, Kabupaten \\ Simalungun \\ ninink207@yahoo.com
}

\begin{abstract}
Langsa City has a mangrove forest area which consists of about 32 species of mangrove in which various mangrove trees in the Langsa City are among the most comprehensive in the world and have an area of approximately 8 thousand hectares. Mangroves are a shelter and breed for various species of birds, monkeys, mammals, fish, crabs, mollusks, reptiles, and insects as well as providing forest products and can be a natural tourist attraction. The Langsa City Government has tried to preserve the existence of mangrove forests by replanting, rehabilitating, issuing village Qanuns relating to mangrove protection and involving local communities as the frontline to protect, cultivate and preserve them. However, it is undeniable that there are still elements who try to take advantage by destroying the existence of mangroves for personal gain. Therefore this article will discuss about claim rights of government to sue, especially the Langsa City Government in tackling the destruction of mangrove forests in its region to uphold the principle of intragenerational equity and the principle of intergenerational equity.
\end{abstract}

Keywords: Actionable Right, government, mangrove forest, the principle of intragenerational equity, the principle of intergenerational equity.

\begin{abstract}
Abstrak Kota Langsa memiliki kawasan hutan mangrove yang terdiri dari sekira 32 species mangrove atau bakau dimana aneka ragam pohon mangrove di kota langsa tersebut termasuk salah satu yang terlengkap didunia dan memiliki luas sekira 8 ribu hektar. Mangrove adalah sebagai tempat berlindung dan berkembang biak berbagai jenis burung, monyet, mamalia, ikan, kepiting, moluska, reptil, dan serangga juga menyediakan hasil hutan serta dapat menjadi obyek wisata alam.Pemerintah Kota Langsa telah berusaha untuk melestarikan keberadaan hutan mangrove dengan melakukan penanaman kembali, rehabilitasi, menerbitkan qanun gampong berkaitan dengan perlindungan mangrove dan melibatkan masyarakat setempat sebagai garis depan untuk melindungi, mengolah dan melestarikannya. Meski demikian, tak dapat dipungkiri bahwa masih ada oknum-oknum yang berusaha untuk mengambil keuntungan dengan merusak keberadaan mangrove untuk mencari keuntungan pribadi. Oleh karenanya dalam artikel ini akan dibahas mengenai hak gugat pemerintah khususnya Pemerintah Kota Langsa dalam menanggulangi tindakan pengrusakan hutan mangrove diwilayahnya untuk menegakkan prinsip keadilan intragenerasin dan prinsip keadilan antar generasi.
\end{abstract}

Kata kunci : Hak gugat, pemerintah, hutan mangrove, prinsip keadilan intra generasi, prinsip keadilan antar generasi. 


\section{Pendahuluan}

Indonesia merupakan negara dengan julukan zamrud katulistiwa dengan garis pantai sepanjang $95.000 \mathrm{~km} 2$ dengan jumlah pulau sekitar 17.000 buah. Dengan kekayaan laut dan darat yang melimpah Indonesia ikut menopang keberadaan dunia. Namun, atas nama pertumbuhan ekonomi dan pembangunan serta kebutuhan ekonomi dalam rangka kesejahteraan masyarakat maka banyak kegiatan usaha yang dilakukan tanpa memperhatikan lingkungan sehingga merusak ekosistem yang telah ada.

Kerusakan lingkungan yang terjadi termasuk keberadaan hutan mangrove dimana hampir 50\% dari total mangrove yang ada di Indonesia telah hilang terutama di Jawa dan Bali. Pemerintah Kota Langsa sebagai kota yang yang memiliki hutan mangrove telah menyadari hal tersebut sehingga berusaha melestarikan keberadaan hutan mangrove, itu sebabnya maka peran pemerintah sangat menentukan keberlangsungan lingkungan yang baik dan lestari.

Pemerintah Kota Langsa saat ini tengah berbenah dan berupaya meningkatkan kualitas kesejahteraan rakyatnya dengan salah satu caranya adalah meningkatkan kualitas lingkungan hidup. Suatu konsep yang sejalan dengan program Kementrian Lingkungan Hidup dan Kehutanan (KLHK) dimana dalam suatu wawancaranya Menteri LHK Ibu Siti Nurbaya $^{1}$ menjelaskan bahwa pentingnya tata kelola hutan untuk kesejahteraan masyarakat.

Mengapa demikian? Karena penurunan kualitas lingkungan hidup tidak hanya berdampak langsung pada kehidupan manusia baik itu dibidang ekonomi dan pembangunan, stabilitas politik dalam negeri, kesehatan masyarakat dan kehidupan sosial tapi juga akan mempengaruhi kondisi iklim global yang akan menghasilkan iklim yang tidak bersahabat. Oleh karenanya penting untuk meningkatkan kesadaran masyarakat untuk lebih bertoleransi dengan lingkungan. Pemerintah sebagai pelopor yang mengajak masyarakatnya sebagai garda depan untuk menjaga kelestarian lingkungannya masingmasing sehingga nantinya akan membawa dampak yang besar bagi kemaslahatan dan kesejahteraan rakyat. Ini adalah suatu pandangan bahwa konsep pembangunan memerlukan suatu etika baru, yang tidak hanya menfokuskan diri pada kelangsungan hidup manusia, tetapi juga menempatkan kepentingan manusia dalam keharmonisan dengan alam. ${ }^{2}$ Meyers dan Muller lebih jauh lagi berpendapat bahwa perubahan etika ini harus menjelaskan perilaku apa yang dapat diterima dan mana yang tidak dapat diterima, terkait dengan hubungan manusia dengan alam. Dalam hal ini, Meyers dan Muller melihat bahwa etika baru pembangunan ini setidaknya memiliki tiga karakteristik.

\footnotetext{
${ }^{1}$ https://mediaindonesia.com/read/detail/191950-tata-kelola-hutan-untuk-kesejahteraanmasyarakat, diakses tanggal 1 November 2019.

${ }^{2}$ Gary D. Meyers dan Simons C. Muller, "The Etical Implications, Political Ramifications and Practical Limitations of Adopting Suistainable Development as National and International Policy," Buffalo Environtmental Law Journal, Vol. 4, 1996, hlm. 36.
} 
Pertama, etika ini harus mampu menjaga proses ekologi yang esensial dan sistem pendukung kehidupan (life supporting system). Kedua, etika ini harus mampu melindungi keanekaragaman genetik. Ketiga, etika ini harus mampu memberikan arahan pada pemanfaatan ekosistem secara berkelanjutan. ${ }^{3}$ Dengan kata lain Meyers dan Muller menyatakan bahwa "the principal ethical implication of adherence to the precepts of ecologically suistainable development is the rcognition that human beings are not the center of life on Earth." ${ }^{4}$ Kesimpulannya bahwa upaya perlindungan lingkungan bukan semata-mata ditujukan bagi kepentingan manusia tapi lebih dari itu semua, upaya perlindungan ini melampaui kepentingan manusia semata dan meliputi kepentingan semua mahkluk yang salah satunya manusia.

Salah satu bagian dari lingkungan yang saat ini sedang digalakkan pembangunannya oleh Pemerintah Kota Langsa adalah pelestarian hutan mangrove. Betapa tidak, dengan pelestarian mangrove, maka beberapa fauna dan endemik lainnya dapat terlindungi. Belum lagi pentingnya hutan mangrove yang dapat menghalangi derasnya ombak yang berpotensi mengikis pantai, keuntungan bagi masyarakat sekitar dengan pengolahan mangrove menjadi bahan makanan yang lezat dan dapat pula dijadikan obyek wisata yang bermanfaat seperti saat ini.

Besarnya manfaat mangrove, tidak hanya itu bahkan kayu mangrove dapat dijadikan kayu arang yang memiliki kualitas ekspor tinggi. Namun, sangat disesalkan bahwa terdapat oknum yang mulai merambah hutan mangrove tanpa peduli untuk melestarikannya kembali. Disinilah timbul hak gugat Pemerintah Kota Langsa sebagai upaya hukum untuk mempertahankan kelestarian hutan mangrove diwilayahnya dari oknum yang tidak bertanggungjawab untuk menegakkan prinsip keadilan intra generasi dan prinsip keadilan antar generasi yang akan kami uraikan dalam pembahasan.

Berdasarkan uraian di atas, maka penulis tertarik untuk mengkaji : 1) bagaimanakah hak gugat pemerintah kota langsa terhadap pengrusakan hutan mangrove? ; 2) bagaimanakah hak gugat pemerintah kota langsa dikaitkan dengan prinsip keadilan intragenerasi dan prinsip keadilan antar generasi?

\section{Metode Penelitian}

Adapun metode penelitian yang digunakan dalam mengkaji permasalahan ini yaitu metode yuridis normatif, dengan pendekatan library research. Data yang dipergunakan adalah data sekunder yang mencakup bahan hukum primer, bahan hukum sekunder, dan bahan hukum tersier. Seluruh data dan bahan yang telah dikumpulkan akan dianalisis secara deskriptif.

${ }^{3}$ Ibid, hlm. 37.

${ }^{4}$ Ibid, hlm. 37-38. 


\section{Pembahasan}

\section{Hak Gugat Pemerintah Kota Langsa Terhadap Pengrusakan Hutan Mangrove}

Pemerintah Indonesia melalui berbagai aturan perundang-undangan telah berusaha meminimalisir dampak negatif terhadap kelestarian lingkungan akibat dari pembangunan. Hal tersebut dapat terlihat dari lahirnya Undang-undang Nomor 4 Tahun 1982, UndangUndang Nomor 23 Tahun 1997 dan terakhir diperbaharui melalui Undang-Undang Nomor 32 Tahun 2009 atau disebut Undang-Undang tentang Perlindungan dan Pengelolaan Lingkungan Hidup (selanjutnya disebut dengan UUPPLH). UUPPLH ini mengandung banyak muatan prinsip-prinsip hukum administrasi Negara dan otonomi daerah.

Undang-undang ini mengatur adanya penguatan mengenai prinsipprinsip perlindungan dan pengelolaan lingkungan hidup yang didasarkan pada tata kelola pemerintahan yang baik karena dalam setiap proses perumusan dan penerapan instrumen pencegahan pencemaran dan atau kerusakan lingkungan hidup serta penanggulangan dan penegakan hukum mewajibkan pengintegrasian aspek transparansi, partisipasi, akuntabilitas, dan keadilan. ${ }^{5}$

Muhammad Natsir dalam tulisannya menyebutkan bahwa lingkungan dalam segala aspek kajiannya dibidang hukum, merupakan salah satu bidang yang paling strategis karena hukum lingkungan setidaknya mencakup tiga aspek yang sangat tinggi yaitu aspek hukum administrasi, aspek hukum pidana, dan aspek hukum perdata. Sehingga untuk memaksimalkan hukum lingkungan tidak mungkin dipaksakan oleh satu lembaha mengingat keterkaitannya antara hukum lingkungan dengan hukum lainnya. ${ }^{6}$

Mengapa harus sarat prinsip hukum administrasi Negara dan otonomi daerah ? karena masalah lingkungan sebagian besar berada dalam wilayah hukum publik dimana Negara mempunyai peran yang lebih besar dalam menentukan arah kebijakan dan perencanaan terhadap sistem perlindungan dan pengelolaan lingkungan hidup, terlebih di dalam sebuah Negara yang merupakan welfare state (Negara kesejahteraan) seperti Indonesia.

Undang-Undang Dasar 1945 sejatinya telah mengatur desain mengenai Negara Kesejahteraan (welfarestate), dimana pemerintahan negara dianggap bertanggung jawab dalam menjamin standar kesejahteraan hidup minimum bagi setiap warga negaranya. Di dalam welfare state, Negara / pemerintah harus berperan aktif untuk menjamin pemenuhan hak-hak warga Negara. Berkaitan dengan lingkungan hidup, dalam

\footnotetext{
${ }^{5}$ Muhammad Natsir, Andi Rachmad, Penetapan Asas Kearifan Lokal Sebagai Kebijakan Pidana dalam Pengelolaan Lingkungan Hidup di Aceh, Jurnal Magister Hukum Udayana, Vol 7 No 4, 2018, hlm. 470

${ }^{6}$ Muhammad Natsir, Membangun Hukum Pidana Lingkungan Berbasis Syariah di Aceh, (Yogyakarta: Deepublish, 2018), hlm. 1
} 
Volume 16, Nomor 1, Januari - Juni 2021

Pasal 65 UUPPLH disebutkan bahwa "setiap orang berhak atas lingkungan hidup yang baik dan sehat sebagai bagian dari hak azasi manusia". Ketentuan pasal ini merupakan perwujudan dari ketentuan Pasal 28H ayat (1) UUD 1945 hasil amandemen yang menyebutkan bahwa "setiap orang berhak hidup sejahtera lahir dan batin, bertempat tinggal, dan mendapatkan lingkungan hidup yang baik dan sehat serta berhak memperoleh pelayanan kesehatan" Dengan alasan filosofis dan yuridis di atas maka UUPPLH memberikan penguatan normatif terhadap peran dan fungsi pemerintah di dalam perlindungan dan pengelolaan lingkungan hidup.

Peran dan fungsi negara tersebut seperti diatur dalam Pasal 36 ayat (1) UUPLH bahwa "setiap usaha dan/atau kegiatan yang wajib memiliki AMDAL atau (Upaya Pengelolaan Lingkungan Hidup dan Upaya Pemantauan Lingkungan Hidup (UKL-UPL) wajib memiliki izin lingkungan". Izin lingkungan yang dikeluarkan oleh pejabat berwenang (menteri, gubernur, bupati/walikota) tersebut harus memenuhi ketentuan terhadap kelengkapan dokumen amdal atau UKL-UPL. Oleh karenanya izin tersebut bertujuan untuk mengarahkan aktifitas para penanggung jawab usaha/kegiatan di dalam melakukan berbagai kegiatan, baik yang langsung berhubungan dengan usaha ekslpoitasi sumber-sumber daya alam maupun secara tidak langsung berhubungan dengan pelestarian lingkungan agar segala usaha dan aktiftas tersebut tidak menimbulkan dampak negatif berupa pencemaran dan/atau perusakan terhadap lingkungan/sumber daya alam sebagaimana diatur dalam Pasal 22 sampai Pasal 34 tentang kewajiban memiliki AMDAL serta kewajiban tentang perizinan lingkungan dalam Pasal 36 sampai Pasal 40.

UUPPLH juga mengatur tentang tugas dan wewenang Pemerintah dan Pemerintah Daerah pada Bab IX Pasal 63 dan Pasal 64. Pasal 63 ayat (1), dimana wewenang Pemerintah Kota dan kabupaten diatur dalam Pasal 63 ayat (3) UUPPLH. Pemerintah memberi kewenangan yang sangat luas kepada Pemerintah Daerah dalam melakukan perlindungan dan pengelolaan lingkungan hidup di daerah masing- masing berupa perencanaan, pemanfaatan, pengendalian, pemeliharaan, pengawasan dan penegakan hukum. Kemudian Pasal 71 sebagai upaya preventif terhadap terjadinya pencemaran dan/atau perusakan lingkungan pada prinsipnya menyatakan bahwa yang mempunyai kewenangan dalam melakukan pengawasan terhadap ketaatan penanggung jawab usaha dan/atau kegiatan di bidang perlindungan dan pengelolaan lingkungan hidup adalah menteri, gubernur atau bupati/walikota dan kewenangan tersebut dapat didelegasikan kepada pejabat/ instansi tekhnis terkait.

Dalam upaya pengawasannya, tentu Pemerintah suatu ketika akan menemukan pencemaran atau pengrusakan lingkungan maka sebagaimana dalam pembahasan artikel ini terdapat hak gugat pemerintah yang diatur dalam Pasal 90 (1) UUPPLH yang menyatakan bahwa : "instansi pemerintah dan pemerintah daerah yang bertanggungjawab di bidang lingkungan hidup berwenang mengajukan gugatan ganti rugi dan tindakan tertentu terhadap usaha dan/atau kegiatan yang menyebabkan pencemaran dan/atau kerusakan lingkungan hidup yang mengakibatkan kerugian 
lingkungan hidup", dimana dalam penjelasannya disebutkan bahwa hak gugat ini dapat diterapkan terhadap kerugian lingkungan hidup yang bukan kerugian terhadap hak milik privat. Pasal tersebut sejalan dengan Pasal 87 ayat (1) UUPPLH yang menyebutkan bahwa "setiap penanggung jawab usaha dan/atau kegiatan yang melakukan perbuatan melanggar hukum berupa pencemaran dan/atau perusakan lingkungan hidup wajib membayar ganti rugi dan/atau melakukan tindakan tertentu". Tindakan hukum tertentu yang dimaksud antara lain: a. Memasang atau memperbaiki unit pengolahan limbah sehingga limbah sesuai dengan baku mutu lingkungan yang ditentukan; b. Memulihkan fungsi lingkungan hidup; dan/atau c. Menghilangkan atau memusnahkan penyebab timbul nya pencemaran dan/atau perusakan lingkungan hidup atau disebut sebagai prinsip pencemar membayar (polluter pays principle). Tindakan pencemaran dan/atau perusakan lingkungan yang dimaksud di dalam Pasal 87 tersebut oleh UUPPLH dinyatakan sebagai suatu perbuatan melanggar hukum. Sebagai suatu perbuatan melanggar hukum, maka ketentuan Pasal 87 merupakan penjabaran khusus dari ketentuan Pasal 1365 KUH Perdata yang menyebutkan bahwa "tiap perbuatan melanggar hukum, yang membawa kerugian kepada orang lain, mewajibkan orang yang karena salahnya mnerbitkan kerugian itu, mengganti kerugian tersebut".

Disinilah letak kelebihan UUPPLH yang baru dibandingkan UUPLH Nomor 23 Tahun 1997 sebab memberi penguatan terhadap prinsip tata kelola pemerintahan yang baik dalam pencegahan pencemaran dan/atau kerusakan lingkungan dan menguatkan semangat otonomi daerah. Dengan adanya penguatan kewenangan pemerintah dan pemerintah daerah dalam upaya perlindungan dan pengelolaan lingkungan hidup diharapkan nantinya akan lebih memberikan perlindungan yang lebih baik terhadap lingkungan hidup termasuk memberikan hak-hak atas lingkungan hidup yang sehat dan bersih terhadap setiap warga negara.

Bagaimana kemudian hak gugat pemerintah dapat dilakukan ? sesuai dengan Peraturan Menteri Negara Lingkungan Hidup Nomor 09 Tahun 2010 tentang Tata Cara Pengaduan dan Penanganan Pengaduan Akibat Dugaan Pencemaran dan/atau Pengrusakan Lingkungan Hidup, yang mengatur bahwa setiap orang mempunyai hak dan peran untuk mengadukan dugaan pencemaran dan/atau pengrusakan lingkungan yang terjadi kepada instansi pemerintah atau pemerintah daerah terkait yang akan melakukan telaah, verivikasi, analisa dan sebagainya sesuai aturan tersebut dimana hasilnya akan diberitahukan kepada pengadu jika tidak terbukti adanya pelanggaran tersebut, atau diberi sanksi administratif kepada pelaku pencemaran dan/ atau pengrusakan lingkungan atau penyelesaian sengketa atau penegakan hukum pidana sesuai pasal 19 aturan ini.

Mengenai penyelesaian sengketa lingkungan, dapat dilakukan diluar pengadilan melalui mekanisme negosiasi, mediasi atau arbitrase dan dapat dilakukan melalui pengadilan sesuai pilihan para pihak sebagaimana diatur dalam Pasal 14 ayat (4) dan Pasal 16 Peraturan Menteri Negara Lingkungan Hidup Nomor 04 Tahun 2013 tentang Pedoman Penyelesaian Sengketa Lingkungan Hidup. Kemudian jika ada pencemaran 
atau pengrusakan, tentunya menimbulkan kerugian maka mengenai hal tersebut dapat mengacu pada Peraturan Menteri Negara Lingkungan Hidup Nomor 13 Tahun 2011 tentang Ganti Kerugian Akibat Pencemaran dan/atau Kerusakan Lingkungan Hidup.

Dengan demikian dalam rangka pelestarian hutan mangrove di Kota Langsa dan segala sesuatu kegiatan yang berkaitan dengan usaha budidaya mangrove tentunya harus memiliki ijin usaha baik AMDAL atau UKL-UPL atau ijin lain yang serupa dari Pemerintah Kota Langsa atau instansi yang mendapat delegasi untuk itu, dimana jika terjadi pencemaran dan/atau pengrusakan terhadap mangrove baik yang diadukan oleh masyarakat maupun yang diperoleh dari hasil penelitian instansi terkait yang berwenang maka Pemerintah Kota Langsa dapat menggunakan haknya untuk menuntut ganti kerugian secara perdata menggunakan hak gugatnya dipengadilan atau melalui penegakan hukum pidana atau menyelesaikan sengketa lingkungan diluar pengadilan melalui negosiasi, mediasi atau arbitrase sekaligus memberikan sanksi administratif berupa pencabutan izin usaha dan izin lingkungan yang bersangkutan.

\section{Hak Gugat Pemerintah Kota Langsa Untuk Menegakkan Prinsip Keadilan Intragenerasi Dan Prinsip Keadilan Antar Generasi}

Mengapa hak gugat pemerintah dikaitkan dengan Prinsip keadilan intra generasi dan prinsip keadilan antar generasi ? Prinsip keadilan intra generasi dan prinsip keadilan antar generasi merupakan elemen dari konsep pembangunan berkelanjutan (sustainable development) yang merupakan hasil proses perdebatan panjang antara kebutuhan akan pembangunan dan kesadaran akan pentingnya perlindungan lingkungan hidup.

Pada tahun 1983, Majelis Umum PBB membuat sebuah lembaga yang bertugas untuk mengkaji ulang beberapa amsalah penting terkait pembangunan dan lingkungan hidup serta merumuskan langkah-langkah untuk mengatasi permasalahan yang terkait, lembaga ini bernama World Commission on Environment and Development (WCED) atau disebut Brundtland Commission. Pada tahun 1987, WCED mengeluarkan laporan berjudul "our common future" dimana dalam laporan tersebut komisi ini mendefinisikan pembangunan berkelanjutan sebagai "development that meets the needs of the present without compromising the ability of future generations to meet their own needs." ${ }^{7}$

Dari definisitersebut, keadilan intra generasiditunjukkanpadakalimat "development that meets the needs of the present ..." bagian ini adalah prioritas utama dari pembangunan berkelanjutan menurut Langhelle, dimana bagian tersebut menunjukkan

7 Sharon Beder, Environmental Principles and Policies : An Interdiciplinary IntroductionEarthscan, (Earthscan, 2006), hlm. 18. 
adanya komitmen dari Negara-negara terhadap keadilan, termasuk redistribusi dari pihak yang kaya kepada yang miskin baik level nasional maupun level internasional. ${ }^{8}$

Keadilan intra generasi setidaknya dapat dilihat dari empat kelompok menurut Kuehn, ${ }^{9}$ yaitu:

a. Keadilan lingkungan sebagai keadilan distributif, yaitu keadilan yang menginginkan adanya alokasi yang lebih adil bagi akses dan manfaat dari sumber daya lingkungan, bagi manfaat perlindungan lingkungan dan bagi biaya perlindungan lingkungan. Dimana secara khusus keadilan ini yang berkaitan dengan prinsip pencemar membayar (polluter pays principle) dan prinsip CBDR atau Common but differential responsibility, yaitu persoalan lingkungan merupakan tanggungjawab bersama tapi beban tanggungjawab tiap Negara berbeda.

b. Keadilan lingkungan sebagai keadilan korektif, yang menginginkan adanya perangkat hukum yang memungkinkan seseorang/Negara yang telah menyebabkan kerugian untuk mengoreksi dan menghilangkan kerugian yang telah ditimbulkannya. Ini juga terkait dengan polluter pays principle.

c. Keadilan lingkungan sebagai keadilan prosedural, yang menginginkan agar hukum mendorong terciptanya sebuah proses yang mampu menjamin bahwa distribusi akan dilakukan secara adil, yang mana terwujud dari pengakuan hak untuk partisipasi, mengambil keputusan dan hak atas informasi, dan

d. Keadilan lingkungan sebagai keadilan sosial, yang melihat bahwa persoalan lingkungan lahir karena ketimpangan sosial sehingga mengentaskan kemiskinan dan menghilangkan kondisi ketidakadilan sosial menjadi bagian dari hal ini.

Selanjutnya dalam definisi pembangunan berkelanjutan diatas, mandat bagi terwujudnya keadilan antar generasi tercermin dalam kalimat "without compromising the ability of future generations to meet their own needs." Jadi pembangunan berkelanjutan menginginkan keadilan terhadap generasi sekarang dan adil pula bagi generasi mendatang. Oleh karenanya konsep keadilan dalam kerangka pembangunan berkelanjutan tidak hanya menitikberatkan pada persoalan alokasi yang adil atas hak dan kewajiban tapi juga mengakui bahwa keutuhan dan integritas lingkungan hidup merupakan bagian tidak terpisahkan dari konsep keadilan. ${ }^{10}$

Edith Brown Weiss, memberikan pandangan bahwa konsep keadilan antar generasi telah melahirkan kewajiban lingkungan (planetary obligations) berupa tiga jenis

8 OlufLanghelle, "Sustainable Development and Social Justice : Expanding the Rawlsian Framework of Global Justice,” Environmental Values, Vol.9, 2000, hlm. 300.

${ }^{9}$ Robert R. Kuehn, “A Taxonomy of Environtmental Justice," Environtmental Law Report, Vol. 30, 2000, hlm. 10681.

${ }^{10}$ Christina Voigt, Sustainable Development as a Principle of International Law : Resolving Conflicts between Climate Measures and WTO Law, Martinus Nijhoff Publishers, 2009, hlm. 52. 
perlindungan, yaitu : perlindungan opsi ( conservation of options), perlindungan kualitas (conservation of quality), dan perlindungan atas akses generasi sekarang dan generasi yang akan datang terhadap sumber daya lingkungan (conservation of access). ${ }^{1}{ }^{1} \mathrm{Ketiga}$ aspek perlindungan tersebut tidak hanya berlaku dalam konteks intra generasi tapi juga konteks antar generasi dimana Weiss mendasari teorinya dari teori keadilan John Rawls. Ketiga aspek tersebut bertujuan agar setiap generasi memiliki tingkat pemanfaatan setidaknya sama dengan tingkat pemanfaatan dari generasi sebelumnya, sambil mendorong terjadinya perbaikan keadaan bagi tiap generasi. Ketiganya berfungsi pula untuk menetapkan batasan bagi tiap Negara ketika mengeksploitasi sumber daya miliknya dan terpenting adalah mengubah asumsi pembangunan, dari asumsi yang mendorong terjadinya konsumsi dan eksploitasi selama belum ada alasan untuk menghentikannya, menjadi asumsi yang menginginkan adanya pemanfaatan sumber daya alam berkelanjutan dan perlindungan lingkungan. ${ }^{12}$

Kedua Prinsip tersebut secara konkrit tercermin dalam Putusan Mahkamah Agung Filipina dalam kasus Minors Oposa v. Factoran, yang memberikan pernyataan pengakuan bahwa hak atas lingkungan hidup yang baik dan sehat merupakan hak konstitusional yang tidak hanya dimiliki oleh generasi sekarang tetapi juga oleh generasi yang akan dating sehingga melahirkan hak gugat (actionable right). Keadilan intra generasi (intragenerational equity), dan keadilan antar generasi (intergenerational equity) berkaitan dengan hak gugat, karena generasi sekarang memiliki hak gugat untuk mempertahankan kepentingan mereka atas lingkungan yang baik dan sehat dan juga untuk mempertahankan kepentingan generasi yang akan dating atas lingkungan yang baik dan sehat.

\section{Penutup}

Berdasarkan uraian diatas, maka dapat ditarik kesimpulan bahwa keberadaan hutan mangrove yang terdapat di Kota Langsa harus senantiasa dijaga kelestariannya untuk kepentingan generasi saat ini dan juga untuk generasi yang akan datang, oleh karenanya melahirkan hak gugat bagi Pemerintah Kota Langsa kepada oknum yang melakukan pengrusakan hutan mangrove sebagai upaya perlindungan dan pelestariannya sebagaimana diatur dalam UUPLH dan Peraturan Menteri Lingkungan Hidup.

Sebagai usulan penulis adalah bahwa hutan mangrove di Kota Langsa semakin hari mengalami penurunan jumlah species dan habitat, karena adanya oknum yang tidak bertanggungjawab dengan melakukan penebangan liar untuk usaha dapur arang, dan sebagainya yang menguntungkan baginya. Untuk itu Pemerintah Kota Langsa harus segera mengambil sikap untuk melindungi hutan mangrove dari kepunahan dengan cara

\footnotetext{
${ }^{11}$ Edith Brown Weiss, "Intergenerational Equity and Rights of Future Generation,"The Modern World of Human Rights : Essays in Honour of Thomas Buergenthal, hlm. 608-609.

${ }^{12}$ Edith Brown Weiss, "Intergenerational Equity in International Law," Proceeding of the Annual Meeting (American Society of International Law), Vol. 81, April 8-11, 1987, hlm. 131.
} 
Volume 16, Nomor 1, Januari - Juni 2021

mengambil tindakan hukum baik secara administrative, pidana ataupun secara perdata (melalui pengadilan atau diluar pengadilan) sehingga pengrusakan hutan khususnya mangrove tidak berkelanjutan.

\section{Daftar Pustaka}

\section{Buku :}

Christina Voigt, Sustainable Development as a Principle of International Law : Resolving Conflicts between Climate Measures and WTO Law, Martinus Nijhoff Publishers, 2009

Edith Brown Weiss, "Intergenerational Equity and Rights of Future Generation,"The Modern World of Human Rights : Essays in Honour of Thomas Buergenthal,

Edith Brown Weiss, "Intergenerational Equity in International Law," Proceeding of the Annual Meeting (American Society of International Law), Vol. 81, April 8-11, 1987

Gary D. Meyers dan Simons C. Muller, "The Etical Implications, Political Ramifications and Practical Limitations of Adopting Suistainable Development as National and International Policy," Buffalo Environtmental Law Journal, Vol. 4, 1996

Muhammad Natsir, Andi Rachmad, Penetapan Asas Kearifan Lokal Sebagai Kebijakan Pidana dalam Pengelolaan Lingkungan Hidup di Aceh, Jurnal Magister Hukum Udayana, Vol 7 No 4, 2018

Muhammad Natsir, Membangun Hukum Pidana Lingkungan Berbasis Syariah di Aceh, Yogyakarta: Deepublish, 2018

OlufLanghelle, "Sustainable Development and Social Justice : Expanding the Rawlsian Framework of Global Justice," Environmental Values, Vol.9, 2000

Robert R. Kuehn, “A Taxonomy of Environtmental Justice," Environtmental Law Report, Vol. 30, 2000

Sharon Beder, Environmental Principles and Policies : An Interdiciplinary IntroductionEarthscan, Earthscan, 2006

\section{Peraturan perundang-Undangan :}

Undang-Undang Nomor 32 Tahun 2009 tentang Perlindungan dan Pengelolaan Lingkungan Hidup

Undang-Undang Nomor 32 Tahun 2004 tentang Pemerintahan Daerah. 
Volume 16, Nomor 1, Januari - Juni 2021

Peraturan Menteri Negara Lingkungan Hidup Nomor 09 Tahun 2010 tentang Tata Cara Pengaduan dan Penanganan Pengaduan Akibat Dugaan Pencemaran dan/atau Pengrusakan Lingkungan Hidup

\section{Internet :}

https://mediaindonesia.com/read/detail/191950-tata-kelola-hutan-untukkesejahteraan-masyarakat, diakses tanggal 1 November 2019. 